\title{
Short communication: Influence of storage and preservation on microbiological quality of silo ovine milk
}

\author{
M. L. de Garnica, ${ }^{\star}$ J. A. Santos, $†$ and C. Gonzalo*1 \\ *Departamento de Producción Animal, Facultad de Veterinaria, Universidad de León, 24071-León, Spain \\ †Departamento de Ciencia y Tecnología de los Alimentos, Facultad de Veterinaria, Universidad de León, 24071-León, Spain
}

\begin{abstract}
This study was designed to analyze the effects of the storage and preservation conditions on counts of mesophilic, thermoduric, psychotrophic, coliform, Escherichia coli, Streptococcus agalactiae, and Staphylococcus aureus organisms in silo ovine milk. A total of 910 analytical determinations were conducted from aliquots of 10 silo ovine milks. The conditions tested were unpreserved and azidiol-preserved milk stored at $4^{\circ} \mathrm{C}$, and unpreserved milk stored at $-20^{\circ} \mathrm{C}$. Milk aged $2,24,48,72$, and $96 \mathrm{~h}$ post-collection for refrigerated aliquots, and 7, 15, and $30 \mathrm{~d}$ post-collection for frozen aliquots. The factors silo and storage conditions significantly contributed to variation of all microbiological variables, although milk age effect within storage was only significant for mesophilic, psychrotrophic, and coliform bacteria counts. In refrigerated raw milk, mesophile, psychrotroph, and coliform counts significantly increased over $96 \mathrm{~h}$ post-collection, whereas the other groups and bacteria species tested maintained their initial concentration. In all cases, azidiol preservation maintained the initial bacterial concentration in raw sheep milk under refrigeration throughout 96 h. Thus, azidiol was a suitable preservative for microbiological studies in sheep milk. Smallest counts were registered for frozen samples, particularly for coliforms, E. coli, Strep. agalactiae and Staph. aureus. Estimates of mesophilic, thermoduric and psychrotrophic organisms showed similar values on both azidiol-preserved and frozen milk samples. Coliforms and E. coli counts significantly decrease over time after freezing. Consequently, freezing at $-20^{\circ} \mathrm{C}$ could also be appropriate for analysis of mesophilic, thermoduric, and psychrotrophic bacterial groups, but not for coliforms or mammary pathogens.
\end{abstract}

Key words: silo milk, bacterial culture, dairy sheep, milk microbiology

Received September 6, 2010.

Accepted December 21, 2010.

${ }^{1}$ Corresponding author: c.gonzalo@unileon.es

\section{Short Communication}

Silo and tank milk are both contaminated by bacteria from different sources, such as flora and pathogens present in beds, milking facilities, wash water, milking systems, udders, teats and teat canals, or mastitic milk. Some of these bacteria are pasteurization-resistant or are able to grow at low temperatures. These characteristics may hinder industrial dairy processing. Some of these species may also be pathogens for humans. Despite this, only aerobic mesophile count determination has been the target of various legal limits or quality payment schemes proposed by different countries. Thus, Regulation (EC) 853/2004 (European Commission, 2004) lays down mesophilic flora limit criterion for milk from other species than cows as $\leq 500,000 \mathrm{cfu} / \mathrm{mL}$, when the final destination of milk does not include heat treatment; or 1,500,000 cfu/mL for heat-treated milk before processing. However, this policy makes no reference to other microbiological criteria, so no regulation exists on other bacterial standards of microbiological quality of sheep milk for many sheep milk-producing countries (e.g., Spain). In this context, other bacterial groups and species studied, such as thermoduric and psychrotrophic flora, coliforms, and Escherichia coli or mastitis-causing pathogens would be of great interest for ovine milk hygiene, safety, quality, and marketing. In all cases, knowledge of the influence of storage and preservation on sheep milk microbiological quality is important both to the farmer and the dairy industry to standardize sampling protocols, to ensure accuracy in test results and to optimize milk storage conditions.

Azidiol (AZ) is a widely used preservative to keep milk samples for several tests in dairy laboratories, although its effects on the viability of major bacterial groups and pathogens in sheep milk need to be well established when such samples are going to be used for microbiological purposes. In this sense, other preservatives (e.g., bronopol) significantly decreased the viability of milk bacterial species and groups (Shepherd et al., 1988; Amores et al., 2010) so AZ effect on sheep milk microbiology should be investigated. Similarly, milk freezing could be of remarkable interest in micro- 
biological studies on sheep milk and in mastitis-control plans due to its potential to decrease processing and collection costs and extend the analytical operation thereof. Thus, studies on goat milk (Sánchez et al., 2003; Amores et al., 2010) show that freezing may be used as a storage method for the study of some bacterial species or groups but not for others. Nonetheless, freezing effect on the viability of major bacterial groups and species present in sheep milk has not yet been studied.

The knowledge of preservation and storage effects on recovering bacterial groups and bacterial pathogens over time would allow the optimum analytical conditions for ovine milk to be defined. This knowledge is needed to implement adequate operational strategies and sampling protocols for practical analysis and research in this species. Silo milk is especially suitable for this purpose as it consists of large mixtures of milk from a large number of herds, which makes the study of different bacterial groups and pathogens possible at the same time. Additionally, such large mixes of milk are the raw material of all dairy products produced by the industry so its microbiological quality has a great economical, technological, hygienic, and marketing interest.

The aim of this study was to determine the effects of the most common storage and preservation conditions on the following microbiological quality variables: aerobic mesophilic, psychrotrophic, thermoduric, coliforms, E. coli, Streptococcus agalactiae, and Staphylococcus aureus bacteria.

Between November 2009 and February 2010, a total of 10 samples of silo sheep milk were collected at a milk plant, which includes milk from 10 different tank milk collection routes, from a total of 400 dairy sheep herds. According to standards recommended by the American Public Health Association (White et al., 1992), samples $(500 \mathrm{~mL})$ were aseptically collected in sterile containers from each of the silos immediately after milk tankers were unloaded. For this experiment, milk stored in each silo corresponded to a single milk tanker from a single collection route. Milk collection frequency in farms was always $48 \mathrm{~h}$, during which the milk was kept at a temperature lower than $6^{\circ} \mathrm{C}$ in cooling tanks in the farms. Milk collection was carried out at the same time in each flock. Silo milk temperature was $4^{\circ} \mathrm{C}$, maintaining that temperature until the bacteriological analysis, which was carried out immediately after arrival in the laboratory in the Department of Food Hygiene and Technology, University of León, Spain. Bulk tank milk of all flocks was periodically checked for antimicrobial detection by Eclipse-100ov screening test (ZEU-Immunotec, Zaragoza, Spain; Montero et al., 2005) in the Dairy Interprofessional Laboratory of Castilla-León region (Spain). In addition, before unloading in silos, tanker milks were always checked for $\beta$-lactams and tetracy- cline drugs by Rosa Charm rapid screening test (Charm Sciences, Inc., Lawrence, MA). Negative results were always obtained during the experiment.

The initial homogenized sample was divided into 13 aliquots of $40 \mathrm{~mL}$ each: 5 aliquots of unpreserved milk were kept refrigerated at $4^{\circ} \mathrm{C}, 5$ aliquots of milk were preserved with AZ (Panreac Quimica S.A., Castellar del Vallès, Barcelona, Spain) and kept refrigerated at $4^{\circ} \mathrm{C}$, and 3 aliquots of unpreserved milk were kept frozen at $-20^{\circ} \mathrm{C}$. Azidiol concentration in preserved samples was always $3.3 \mu \mathrm{L} / \mathrm{mL}$ (i.e., $133 \mu \mathrm{L} / 40 \mathrm{~mL}$ ). Azidiol composition was $75 \mathrm{mg}$ of chloramphenicol, $1 \mathrm{~mL}$ of ethanol, $1.8 \mathrm{~g}$ of sodium azide, $4.5 \mathrm{~g}$ of trisodium citrate $5 \mathrm{H}_{2} \mathrm{O}$, and $35 \mathrm{mg}$ of bromophenol blue in 100 $\mathrm{mL}$ of distilled water. Bacteriological analysis of refrigerated aliquots was carried out at 2, 24, 48, 72, and $96 \mathrm{~h}$ post-collection. Frozen aliquots were defrosted at $4^{\circ} \mathrm{C}$ overnight and analyzed at 7,15 , and $30 \mathrm{~d}$ postcollection.

Total aerobic plate count determination was performed following the standards recommended by the American Public Health Association (APHA) for milk and dairy products (White et al., 1992). The total number of viable bacterial cells was determined by the SPC method. Milk samples were subjected to serial dilution in the $10^{-1}$ to $10^{-5}$ range and inoculated into plate count agar (PCA; Oxoid Limited, Cambridge, UK) petri plates. The inoculated plates were incubated at 30 $\pm 1^{\circ} \mathrm{C}$ for $48 \mathrm{~h}$. Thermoduric count was carried out by the SPC method after laboratory pasteurization at 62.8 $\pm 0.5^{\circ} \mathrm{C}$ for $30 \mathrm{~min}$ following APHA recommendations (White et al., 1992). Psychrotrophic bacteria count was also performed by $\mathrm{SPC}$, plates being incubated at $7^{\circ} \mathrm{C}$ between 7 and $10 \mathrm{~d}$ (White et al., 1992). The enumeration of coliforms and E. coli was carried out using $3 \mathrm{M}$ Petrifilm E. coli/coliform count plates (3M, St. Paul, Minnesota) according to the manufacturer instructions. In all cases plates were inoculated with $1 \mathrm{~mL}$ of milk sample dilution in the range of $10^{-1}$ and $10^{-3}$. Plates were incubated at $37 \pm 0.5^{\circ} \mathrm{C}$ for 24 to $48 \mathrm{~h}$. Enumeration of each group consisted of considering as confirmed coliforms red and blue colonies with associated gas bubbles. Confirmed E. coli were considered as blue colonies with associated gas bubbles. Results were expressed as cfu/mL. Regulation UNE-EN ISO 6888-2:1999/ Amd 1:2003 (ISO, 2003) was used as the reference method for Staph. aureus enumeration. Finally, Edwards Medium Modified (Oxoid Limited, Cambridge, UK) supplied with 5 to $7 \%$ defibrinated sheep blood (Oxoid Limited) was used for Strep. agalactiae detection and enumeration (Zadoks et al., 2004). Incubation was at $35^{\circ} \mathrm{C}$ for $48 \mathrm{~h}$. Hemolytic and nonhemolytic, esculinnegative blue colonies were suspected of being Strep. agalactiae. These colonies were tested for confirmation 
Table 1. Descriptive statistics for microbiological variables studied in silo ovine milk

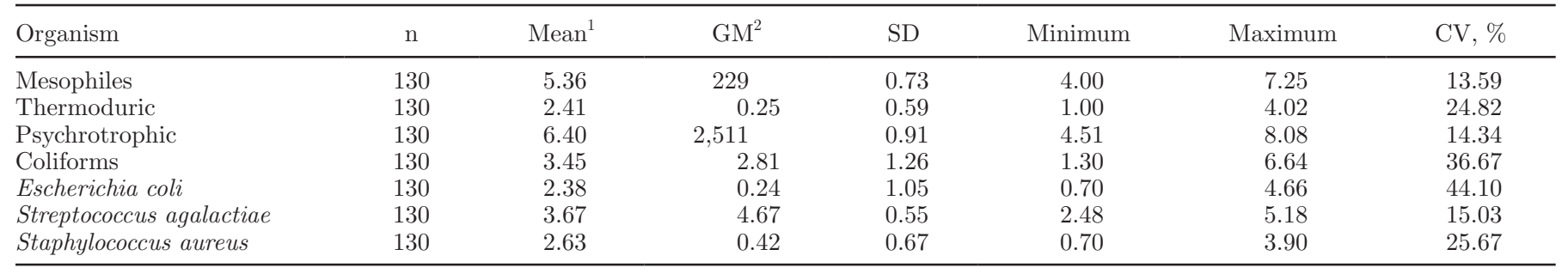

${ }^{1}$ Logarithm of cfu/mL.

${ }^{2}$ Geometric mean $\times 10^{3} \mathrm{cfu} / \mathrm{mL}$.

by the Christie, Atkins, and Munch-Petersen (CAMP) test, catalase and oxidase tests, and detection of Strep. agalactiae by PCR (Martinez et al., 2001) to ensure the results.

The milk composition and SCC of each silo sample was determined with COMBIFOSS $6000 \mathrm{FC}$ (Foss Electric, Hillerød, Denmark), subjected to quality controls and inter-comparative trials. Mean values $\pm \mathrm{SD}$ for fat, total protein, and total solids content and SCC were: $6.92 \pm 0.49 \%, 5.41 \pm 0.19 \%, 18.03 \pm 0.60 \%$, and $998 \pm$ $51 \times 10^{3}$ cells $/ \mathrm{mL}$.

The statistical analysis was carried out by the GLM procedure of SAS (SAS Institute, 1998). The model used was: $Y_{i j k}=M_{i}+S_{j}+A_{k: j}+e_{i j k}$, where $Y_{i j k}$ was the dependent variable logarithm of $\mathrm{cfu} / \mathrm{mL}$ of bacterial groups and species studied (mesophilic, thermoduric, psychotropic, coliform, E. coli, Strep. agalactiae, and Staph. aureus bacteria); $M_{i}$ was the silo effect (10 levels); $S_{j}$ was the storage effect (3 levels: unpreserved milk stored at $4^{\circ} \mathrm{C}, \mathrm{AZ}$-preserved milk stored at $4^{\circ} \mathrm{C}$, and unpreserved milk stored at $\left.-20^{\circ} \mathrm{C}\right) ; A_{k: j}$ was the age effect within storage $(2,24,48,72$, and 96 h post-collection for unpreserved and AZ-preserved refrigerated milk, and 7, 15, and $30 \mathrm{~d}$ for frozen milk); and $e_{i j k}$ was the residual error. A second mathematical model was only used for samples stored at $4^{\circ} \mathrm{C}$, following the same GLM procedure of SAS with the objective of studying the effect of preservation $\times$ age interaction, as a factor of the statistical model. This model was: $Y_{i j k}=M_{i}+$ $P_{j}+A_{k}+P A_{j k}+e_{i j k}$, where $M_{i}$ was the silo effect (10 levels); $P_{j}$ was the preservation effect (2 levels: unpreserved and AZ-preserved milk); $A_{k}$ was the milk age effect $\left(2,24,48,72\right.$, and $96 \mathrm{~h}$ post-collection); and $P A_{j k}$ was the preservation $\times$ age interaction effect.

The statistics of the microbiological variables studied are shown in Table 1. Psychrotrophic bacteria were the most numerous bacterial group (6.40 $\log \mathrm{cfu} / \mathrm{mL}$ ) above mesophilic flora (5.36 log cfu/mL), coliform (3.45 $\log \mathrm{cfu} / \mathrm{mL})$, and thermoduric flora $(2.41 \log \mathrm{cfu} / \mathrm{mL})$. In general, these counts were consistent with those reported by Sanjuan et al. (2003) in bulk tank milk from sheep flocks, but higher than those found in cow milk (Jayarao et al., 2004). Lower individual milk production and the absence of teat washing before milking, as well as poorer facilities than those for cattle, could explain the higher bacterial counts found in ewe milk compared with cow milk. Nevertheless, the geometric mean of mesophilic flora found in silo milk for the storage and preservation conditions studied $\left(229 \times 10^{3}\right.$ $\mathrm{cfu} / \mathrm{mL}$ ) was below the lower limit of $500,000 \mathrm{cfu} / \mathrm{mL}$ established by the European Union regulations for bulk tank milk from sheep and goat flocks.

Regarding bacterial species studied, E. coli count $(2.38 \log \mathrm{cfu} / \mathrm{mL})$ represented $8.5 \%$ of the total coliform estimate, a similar percentage to $7.4 \%$ found in sheep silo milk by Cosentino and Palmas (1997), but higher than $1.5 \%$ obtained by Sanjuan et al. (2003) in ewe bulk tank milk. Counts of contagious mastitis pathogens Strep. agalactiae (3.67 log $\mathrm{cfu} / \mathrm{mL})$ and Staph. aureus (2.63 log cfu/mL) were elevated and indicative of mammary infections and high SCC from dairy sheep flocks. These results suggest the need to increase mastitis control programs in herds to decrease the prevalence of contagious mastitis in dairy sheep (Linage and Gonzalo, 2008; Gonzalo et al., 2010).

Effects of silo ( $F$ between 4.44 and $34.21 ; P<0.001$ ) and storage conditions ( $F$ between 6.98 and 109.13; $P<0.01$ to $P<0.001)$ contributed significantly to $\log \mathrm{cfu} / \mathrm{mL}$ variations for all variables involved in this study. The effect of milk age within storage was also significant for mesophilic $(F=12.69 ; P<0.001)$, psychrotrophic $(F=5.39 ; P<0.001)$, and coliforms $(F=$ 5.79; $P<0.001)$ bacteria, but not for the rest of groups and bacterial species $(P>0.05)$.

The effect of storage on the concentration of all variables is shown in Table 2. Non-preserved refrigerated milk showed higher counts $(P<0.05)$ than did AZ-preserved refrigerated milk for all bacterial groups, apart from bacterial species E. coli, Strep. agalactiae and Staph. aureus, whose concentration did not differ. Counts after freezing were lower $(P<0.05)$ than those obtained for non-preserved refrigerated milk, although 
Table 2. Least squares means ( $\log \mathrm{cfu} / \mathrm{mL} \pm \mathrm{SE}$ ) of microbiological variables of silo ovine milk affected by storage, and statistical significance

\begin{tabular}{lcccc}
\hline Organism & $\begin{array}{c}\text { Unpreserved } \\
\text { milk, } 4^{\circ} \mathrm{C}\end{array}$ & $\begin{array}{c}\text { Azidiol-preserved } \\
\text { milk, } 4^{\circ} \mathrm{C}\end{array}$ & $\begin{array}{c}\text { Unpreserved } \\
\text { milk, }-20^{\circ} \mathrm{C}\end{array}$ & $F$-value \\
\hline Mesophiles & $5.91 \pm 0.05^{\mathrm{a}}$ & $5.04 \pm 0.05^{\mathrm{b}}$ & $4.97 \pm 0.07^{\mathrm{b}}$ & $86.54^{* * * *}$ \\
Thermoduric & $2.61 \pm 0.06^{\mathrm{a}}$ & $2.36 \pm 0.06^{\mathrm{b}}$ & $2.18 \pm 0.08^{\mathrm{b}}$ & $9.03^{* * *}$ \\
Psychrotrophic & $7.04 \pm 0.08^{\mathrm{a}}$ & $6.07 \pm 0.08^{\mathrm{b}}$ & $5.89 \pm 0.10^{\mathrm{b}}$ & $53.32^{* * *}$ \\
Coliforms & $4.58 \pm 0.10^{\mathrm{a}}$ & $2.90 \pm 0.10^{\mathrm{b}}$ & $2.49 \pm 0.12^{\mathrm{c}}$ & $109.13^{* * *}$ \\
Escherichia coli & $2.67 \pm 0.07^{\mathrm{a}}$ & $2.62 \pm 0.07^{\mathrm{a}}$ & $1.51 \pm 0.09^{\mathrm{b}}$ & $57.51^{* * *}$ \\
Streptococcus agalactiae & $3.84 \pm 0.06^{\mathrm{a}}$ & $3.73 \pm 0.06^{\mathrm{a}}$ & $3.31 \pm 0.07^{\mathrm{b}}$ & $17.37^{* * *}$ \\
Staphylococcus aureus & $2.75 \pm 0.06^{\mathrm{a}}$ & $2.68 \pm 0.06^{\mathrm{a}}$ & $2.36 \pm 0.08^{\mathrm{b}}$ & $6.98^{* *}$ \\
\hline
\end{tabular}

${ }^{\mathrm{a}-\mathrm{c}}$ Means within a row with different superscripts differ $(P<0.05)$.

${ }^{* *} P<0.01 ; * * * P<0.001$.

mesophilic, psychrotrophic, and thermoduric bacteria showed similar counts $(P>0.05)$ to those from AZpreserved refrigerated milk. After thawing, the counts of coliforms, E. coli, Strep. agalactiae, and Staph. aureus $(2.49,1.51,3.31$, and $2.36 \log \mathrm{cfu} / \mathrm{mL}$, respectively) were significantly lower than those obtained for non-preserved refrigerated milk $(4.58,2.67,3.84$, and $2.75 \log \mathrm{cfu} / \mathrm{mL}$, respectively) or for AZ-preserved refrigerated milk $(2.90,2.62,3.73$, and $2.68 \log \mathrm{cfu} /$ $\mathrm{mL}$, respectively). Several authors (Villanueva et al., 1991; Godden et al., 2002) have investigated the effect of freezing on bacteriological culturing of Staph. aureus and other mastitis-causing pathogens from milk samples. It has been postulated that freezing process may rupture milk macrophages and neutrophils, releasing phagocytized bacteria, and also that freezing may disrupt bacterial cell aggregates. Thus, the number of $\mathrm{cfu} / \mathrm{mL}$ should increase, thereby improving the sensitivity of microbiological culture. However, other authors did not find any significant effect of freezing on the number of positive samples of streptococci or Staph. aureus in mastitic cow milk after 16 wk (Schukken et al., 1989), and Godden et al., (2002) observed differences in freezing effect for pre-milking and post-milking samples from Staph. aureus mastitic quarters. No information concerning changes in concentration of these mammary pathogens for frozen silo milk has been published, but our results indicated a decrease of mammary pathogens concentration after freezing.

The study of preservation $\times$ age interaction in refrigerated milk samples (Table 3 ) revealed statistically significant differences only for groups of mesophilic, psychrotrophic, and coliforms bacteria, in which counts increased significantly over time in non-preserved milk. The highest concentration was for psychrotrophic flora even at the time of silo sampling. These results were consistent with those obtained by Sanjuan et al. (2003), which showed a significant increasing concentration of Pseudomonas spp. from the time of milking (4.07 $\log \mathrm{cfu} / \mathrm{mL}$ ) until $96 \mathrm{~h}$ after milking (7.21 log cfu/
$\mathrm{mL}$ ) in ovine milk refrigerated at $6^{\circ} \mathrm{C}$. Thus, the psychrotrophic flora of milk becomes predominant a few hours after milking. Because of the high concentration of psychrotrophic flora and its proven relationship with a high incidence of degradative actions (i.e., lipases of Pseudomonas spp.) on milk and cheese components, it is advisable to collect and process the milk (e.g., delivery, heat treatment) in the shortest time possible to prevent significant decline in milk and dairy product quality.

Azidiol-preservation and storage at $4^{\circ} \mathrm{C}$ kept over time the same initial counts of non-preserved milk (Table 3 ). Consequently, this procedure could be used by dairy laboratories (interprofessional, industry, research) or by quality payment schemes to determine the initial bacterial counts in silo or bulk tank milk, particularly in the case of mesophiles, psychrotrophic, and coliforms organisms. This is a relevant aspect, as AZ preservation is compatible with composition and SCC analysis in small ruminant milk (Gonzalo et al., 2004; Sánchez et al., 2005); thus, only 1 AZ-preserved milk sample could be sufficient for composition, SCC, and bacterial count analysis from bulk tank or silo milks.

In reference to freezing, the effect of sample age was not significant on the concentration of the microbial groups studied, except for coliforms and $E$. coli counts, which decreased $(P<0.05)$ from d $7(2.84$ and $1.94 \mathrm{log}$ $\mathrm{cfu} / \mathrm{mL}$, respectively) until d 30 (2.25 and $1.18 \mathrm{log} \mathrm{cfu} /$ $\mathrm{mL}$, respectively) post-freezing. In cow milk, evidence exists for a decrease both in the viability of $E$. coli at $-20^{\circ} \mathrm{C}$ (Pankey et al., 1987) and in the diagnostic sensitivity of this organism after freezing (Schukken et al., 1989), which is consistent with our results.

In conclusion, unpreserved silo sheep milk stored at $4^{\circ} \mathrm{C}$ significantly increased the concentration of mesophiles, psychrotrophic, and coliform bacteria over time, which makes it advisable to rapidly process the milk stored in silos to avoid its rapid deterioration. The initial concentration of thermoduric, E. coli, Strep. agalactiae and Staph. aureus remained, however, invari- 
Table 3. Least squares means $(\log \mathrm{cfu} / \mathrm{mL})$ of microbiological variables of refrigerated silo ovine milk $\left(4^{\circ} \mathrm{C}\right)$ affected by preservation and age, and statistical significance

\begin{tabular}{|c|c|c|c|c|c|c|c|c|c|c|c|}
\hline \multirow[b]{2}{*}{ Organism } & \multicolumn{5}{|c|}{ Unpreserved milk } & \multicolumn{5}{|c|}{ Azidiol-preserved milk } & \multirow[b]{2}{*}{$F$-value } \\
\hline & $2 \mathrm{~h}$ & $24 \mathrm{~h}$ & $48 \mathrm{~h}$ & $72 \mathrm{~h}$ & $96 \mathrm{~h}$ & $2 \mathrm{~h}$ & $24 \mathrm{~h}$ & $48 \mathrm{~h}$ & $72 \mathrm{~h}$ & $96 \mathrm{~h}$ & \\
\hline Mesophiles $^{1}$ & $5.13^{\mathrm{a}}$ & $5.47^{\mathrm{b}}$ & $5.86^{\mathrm{c}}$ & $6.33^{\mathrm{d}}$ & $6.78^{\mathrm{e}}$ & $5.03^{\mathrm{a}}$ & $4.97^{\mathrm{a}}$ & $5.08^{\mathrm{a}}$ & $4.93^{\mathrm{a}}$ & $5.18^{\mathrm{ab}}$ & $14.74^{* * *}$ \\
\hline Thermoduric ${ }^{2}$ & 2.47 & 2.34 & 2.56 & 2.72 & 2.97 & 2.34 & 2.29 & 2.45 & 2.31 & 2.40 & $1.34^{\mathrm{NS}}$ \\
\hline Psychrotrophic ${ }^{3}$ & $6.03^{\mathrm{a}}$ & $7.02^{\mathrm{b}}$ & $7.06^{\mathrm{b}}$ & $7.35^{\mathrm{bc}}$ & $7.77^{\mathrm{c}}$ & $6.05^{\mathrm{a}}$ & $5.99^{\mathrm{a}}$ & $6.02^{\mathrm{a}}$ & $6.09^{\mathrm{a}}$ & $6.19^{\mathrm{a}}$ & $6.77^{* * *}$ \\
\hline Coliforms ${ }^{4}$ & $3.44^{\mathrm{a}}$ & $4.17^{\mathrm{b}}$ & $4.72^{\mathrm{bc}}$ & $5.17^{\mathrm{cd}}$ & $5.39^{\mathrm{d}}$ & $3.15^{\mathrm{ae}}$ & $2.91^{\mathrm{ae}}$ & $2.90^{\mathrm{ae}}$ & $2.59^{\mathrm{e}}$ & $2.95^{\mathrm{ae}}$ & $9.22^{* * *}$ \\
\hline Escherichia coli & 2.79 & 2.43 & 2.62 & 2.69 & 2.80 & 2.69 & 2.62 & 2.62 & 2.63 & 2.53 & $1.04^{\mathrm{NS}}$ \\
\hline Streptococcus agalactiae ${ }^{6}$ & 3.64 & 3.64 & 3.91 & 3.86 & 4.13 & 3.77 & 3.64 & 3.74 & 3.73 & 3.76 & $1.03^{\mathrm{NS}}$ \\
\hline Staphylococcus aureus ${ }^{7}$ & 2.69 & 2.62 & 2.92 & 2.72 & 2.80 & 2.64 & 2.95 & 2.81 & 2.58 & 2.39 & $2.25^{\mathrm{NS}}$ \\
\hline
\end{tabular}

${ }^{\mathrm{a} e} \mathrm{Means}$ within a row with different superscripts differ $(P<0.05)$.

${ }^{1} \mathrm{SE}=0.11$.

${ }^{2} \mathrm{SE}=0.14$.

${ }^{3} \mathrm{SE}=0.16$.

${ }^{4} \mathrm{SE}=0.22$.

${ }^{5} \mathrm{SE}=0.12$.

${ }^{6} \mathrm{SE}=0.13$.

${ }^{7} \mathrm{SE}=0.13$.

$* * * P<0.001$.

able. Storage at $4^{\circ} \mathrm{C}$ of $\mathrm{AZ}$-preserved sheep milk was a suitable method to maintain the initial concentration for all studied bacterial groups and species, particularly for mesophilic, psychrotrophic, and coliform organisms throughout $96 \mathrm{~h}$. Freezing significantly decreased the viability of coliforms, E. coli, Strep. agalactiae and Staph. aureus.

\section{ACKNOWLEDGMENTS}

This study was supported by project AGL2008-00422 of the Spanish Ministry of Education and Science Ministry of Science and Innovation, Government of Spain (Madrid). The authors thank L. Fernando De La Fuente (Dpt. Producción Animal, Universidad de León, Spain) for statistical advice, and David Bradley (Veterinary Laboratories Agency, Weybridge, New Haw, Surrey, UK) for reviewing the English version of this work.

\section{REFERENCES}

Amores, J., A. Sánchez, A. G. Martín, J. C. Corrales, A. Contreras, and C. de la Fe. 2010. Viability of Mycoplasma agalactiae and Mycoplasma mycoides ssp. capri in goat milk samples stored under different conditions. Vet. Microbiol. 145:347-350.

Cosentino, S., and F. Palmas. 1997. Hygienic conditions and microbial contamination in six ewe's-milk-processing plants in Sardinia, Italy. J. Food Prot. 60:283-287.

European Commission. 2004. Regulation (EC) No 853/2004 of the European Parliament and of the Council of 29 April 2004 laying down specific hygiene rules for on the hygiene of foodstuffs. OJ L $139,30.04 .2004$

Godden, S. M., J. T. Jansen, K. E. Leslie, N. L. Smart, and D. F. Kelton. 2002. The effect of sampling time and sample handling on the detection of Staphylococcus aureus in milk from quarters with subclinical mastitis. Can. Vet. J. 43:38-42.
Gonzalo, C., J. C. Boixo, J. A. Carriedo, and F. San Primitivo. 2004 Evaluation of rapid somatic cell counters under different analytical conditions in ovine milk. J. Dairy Sci. 87:3623-3628.

Gonzalo, C., J. A. Carriedo, M. C. García-Jimeno, M. Pérez-Bilbao, and L. F. de la Fuente. 2010. Factors influencing variation of bulk milk antibiotic residue occurrence, somatic cell count and total bacterial count in dairy sheep flocks. J. Dairy Sci. 93:1587-1595.

ISO. 2003. UNE-EN ISO 6888-2:1999/ Amd 1:2003. Horizontal method for the enumeration of coagulase-positive staphylococci (Staphylococcus aureus and other species). International Organization for Standardization, Geneva, Switzerland.

Jayarao, B. M., S. R. Pillai, A. A. Sawant, D. R. Wolfgang, and N. V. Hegde. 2004. Guidelines for monitoring bulk tank milk somatic cell and bacterial counts. J. Dairy Sci. 87:3561-3573.

Linage, B., and C. Gonzalo. 2008. Influence of an intramammary infusion at drying-off of combined penethamate hydriodide, benethamine penicillin, and framycetin sulfate on intramammary infections and somatic cell counts in dairy sheep. J. Dairy Sci. 91:3459-3466.

Martinez, G., J. Harel, and M. Gottschalk., M. 2001. Specific detection by PCR of Streptococcus agalactiae in milk. Can. J. Vet. Res. 65:68-72.

Montero, A., R. L. Althaus, A. Molina, I. Berruga, and M. P. Molina. 2005. Detection of antimicrobial agents by a specific microbiological method (Eclipse 100) for ewe milk. Small Rumin. Res. $57: 229-237$.

Pankey, J. W.. J. K. Wadsworth, K. H. Metha, and P. A. Murdough. 1987. Effects of storage on viability of mastitis pathogens. J. Dairy Sci. 70(Suppl. 1):132. (Abstr.)

Sánchez, A., A. Contreras, J. Jiménez, C. Luengo, J. C. Corrales, and C. Fernández. 2003. Effect of freezing goat milk samples on recovery of intramammary bacterial pathogens. Vet. Microbiol. 94:71-77.

Sánchez, A., D. Sierra, C. Luengo, J. C. Corrales, C. T. Morales, A Contreras, and C. Gonzalo. 2005. Influence of storage and preservation on Fossomatic cell count and composition of goat milk. J. Dairy Sci. 88:3095-3100.

Sanjuan, S., J. Rúa, and M. R. García-Armesto. 2003. Microbial flora of technological interest in raw ovine milk during $6^{\circ} \mathrm{C}$ storage. Int. J. Dairy Technol. 56:143-148.

SAS Institute. 1998. SAS User's Guide: Statistics. Release 6.12. SAS Inst., Inc., Cary, NC. 
Schukken, Y. H., J. A. H. Smit, F. J. Grommers, D. Vandegeer, and A. Brand. 1989. Effect of freezing on bacteriologic culturing of mastitis milk samples. J. Dairy Sci. 72:1900-1906.

Shepherd, J. A., R. D. Waigh, and P. Gilbert. 1988. Antibacterial action of 2-bromo-2-nitropropane-1,3-diol (Bronopol). Antimicrob. Agents Chemother. 32:1693-1698.

Villanueva, M. R., J. W. Tyler, and M. C. Thurmond. 1991. Recovery of Streptococcus agalactiae and Staphylococcus aureus from fresh and frozen bovine milk. J. Am. Vet. Med. Assoc. 198:1398-1400.
White, C. H., J. R. Bishop, and D. M. Morgan. 1992. Microbiological methods for dairy products. Pages 59-323 in Standard Methods for the Examination of Dairy Products. R. T. Marshall, ed. American Public Health Association (APHA), Washington, DC.

Zadoks, R. N., R. N. González, K. J. Boor, and Y. H. Schukken. 2004. Mastitis-causing streptococci are important contributors to bacterial counts in raw bulk tank milk. J. Food Prot. 67:2644-2650. 